Commission. He goes to the Bodleian Library for the special task of cataloguing the vast papors of Lord Bryce, papers which pronise to furnish much information on British manipulation of American opinion in the First World War. The Survey has made some contribution towards persuading the Bodleian to make these papurs available at an early date.

Though we are now too close to publication to make it worth while to relate interesting finds, one exception may be allowed. Many will have looked with envy at the John Cloments' Library, Michigan, for 1ts possession of the Gage Papers relating to military oporations in the War of Independence. These were sold to the Library by the present Lord Gage in the early 1930s. However, his ancestor, the "great Gage", also held much American land before the war, through his wife, in South Carolina and New York; and after the war, through an American branch of the family, he converted most of his land into American stock and investments. These papers were not sold, as they formed part of the Estate Papors. At our request, Lord Gage has now very helpfully consented to deposit these in the Barbican House Library, Lewes, Sussex, where they will shortly be available for scholarly inspection. $\Lambda_{s}$ they cover a period from 1750 to about 1855 and involve long and expert letters of advice from his American agents and cousins about the state of the Anerican market, particularly in the 1820s and on to the time of railroad investment, they should prove interesting to many economic historians.

A duplicated list of American newspapers in United Kingdon libraries will be available within the next six weeks, and the work has begun of analysing the appalling results of the library check-lists of printed books relating to Amorican history and literature. This part of the report (which will appear separately, of course) should at least interest University librarians. I have now got to go out with a reporter from a Gloucestershire paper to meet the descendant of someone whose emigrant letters we found; it is a fair courtesy in return for a column appealing for emigrant letters.

\title{
BERNARD CRICK.
}

\section{NEWS OF PAPER-BACKS}

The spate of American paper-back books shows no signs of ceasing. Should there still be some B.A.A.S. members who are unaware of the richness of the works in this form, it is hoped that this brief note will draw their attention to the values of American paper-backs. Not only are many old friends made available at cheap prices, s uch as a new edition of The Adventures of Huckleberry Finn, edited by Henry Nash Smith, which is in preparation for the inexpensive Riverside Edition of Houghton Mifflin, but works which have been out-of-print for tor long are given a new lease of life in paper-backs. A good example of this is Elmer T. Clark's The Small Sects in America (Apex Books, Abingdon Press, \$1.25), which has been virtually unobtainable for many years, and which anyone who wishes to trace the tortuous mazes of the influence of American sectarianism abroad that are sketched by the first two articles in this issue of the Bullotin will be forced to use.

Cambridge University Press informs us that they are publishing in this country paper-back books from the Presses of the Universities of Chicago and California. Perhaps the most interesting items for students of American history and institutions in their recent lists which we have received are from Chioago: Louis Wirth's The Ghetto $(\$ 1.25)$, on the American Jew; Ernest Staples Osgood's The Day of the Cattleman (\$1.50); and R. S. Crane's Critics and Criticism, an abridged edition of a book of critical essays from the so-called "Chicago" school. 